\title{
Security, city and democracy
}

CrossMark

Mauro Tebaldi*

\begin{abstract}
This article analyses the relations between security, urban governance and democratic quality in the light of the fundamental theoretical trends and principal empirical researches present in the socio-political literature. After introducing the theme from a conceptual point of view, the article reviews the interpretations and explanatory hypotheses, dwelling on the problems each explanation leaves unsettled. In the conclusion there is a discussion on whether urban governance may be considered the most suitable territorial level to improve security policies and democratic quality. To this end, an interpretative hypothesis is introduced that challenges the most consolidated explanations and opens up new perspectives for research.
\end{abstract}

Keywords: Security policies, State, Urban governance, Local government, Democracy, Quality of democracy

\section{Background}

The theme of security is particularly important in the development of contemporary democracies. It becomes especially salient in the city environment: cities are the prevalent subject of attacks against collective security; in urban contexts the main social, political and economic tensions accumulate relating to the management of security; it is above all the cities that experiment with the most innovative policy instruments aimed at managing security. In the light of these observations, some points are raised that could be summarized in the following questions: what are the concepts and dimensions of analysis enabling that systematic procedures and decisions on security in the various territorial spheres can be examined? Which problems have been opened up by the socio-political literature that has theoretically and empirically analyzed security policies in a perspective of improvement of democratic quality? Finally, can we think of the urban dimension as an optimizing dimension for improving security policies and the quality of contemporary democracies?

This article aims to respond to the questions formulated above, dealing with them in three parts. In the first part, the conceptual foundations are presented; in the second part, the issues are discussed that fuel the

*Correspondence: tebaldi@uniss.it

Department of Political Sciences, Communication Sciences

and Information Engineering, University of Sassari, Sassari, Italy scientific debate on the relations between security and democratic quality at different levels of analysis; in the third part, new hypotheses and ways of interpreting are put forward.

\section{Fundamental concepts and definitions Security and politics}

In its general meaning, and with reference to human aggregates, security, as suggested by the Latin etymology of the word, describes behaviors, conduct and attitudes, both individual and collective, engaged in (or that can be engaged in) sine cura. To be more specific, security, understood in the social sense, concerns the conditions that allow individuals to carry on their existence without worrying, considering minimal or completely absent any danger or risk for their physical integrity, for safeguarding their collective and personal effects, and for the protection of the environment they live and work in.

These conditions are particularly important when individual behaviors takes place within collectivities organized and steered by government authorities. When, that is, they are situated in political communities.

In the definition of politics accepted here, as "sphere of the sovereign, legitimate, collectivized decisions", the reference to the "vertical dimension" of political activity is clear, from which, according to Sartori (1980), the actual identity of politics and its separation from the other spheres of human action springs. As Sartori also maintains, thanks to its situation along the vertical 
dimension "the political sphere becomes elevated and circumscribed, in the sense that it is taken back to government activity and, basically, to the State sphere" (Sartori 1980: 206). This reference to the verticality of politics implies moreover that: "as long as a political system is maintained, the prevalent, binding rules erga omnes are and remain the rules issued by political authorities. Only political decisions-it is not important if they are in the form of laws or not-are applied with binding strength to the general mass of citizens" (Sartori 1980: 208).

In the case of organized human aggregates, it is indeed the collective need of security, of acting sine cura as regards the dangers and risks of uncontrolled violence, that expresses the fundamental condition from which the essence itself of politics comes down, namely the application of a system of government capable of imposing rules erga omnes and possible sanctions for those who break them. This ability to govern depends, in turn, on two factors: (a) on the degree of monopolistic control carried out over the material and organizational instruments of violence; (b) on the degree of acceptance of that power by each individual belonging to the community, i.e. the degree of legitimacy enjoyed by those holding political power.

The guarantee of security provided by an institutional subject (the government) entitled to monopolistically organize, control and manage violence through specific structures is manifested in two dimensions. In the internal dimension, through the dual requisites already mentioned above of possession of the organizational resources and instruments of violence and the legitimacy of its monopolistic use with all members of the community to ensure peaceful order. In the external dimension, through those same organizations and instrument of violence, to safeguard the territorial confines by self-defense from the threats of other sovereign states, in a context tending towards international anarchy.

If, therefore, the concepts of security and politics seem intimately related, it is not surprising that the issue of security has stimulated a considerable amount of theoretical and empirical researches in all the fields of social sciences. With a special focus to political science, we can classify security studies according to at least one criteria: the political-territorial dimension of security as a public good. In fact, it can be said that the territorial extension is capable to determine the fruition of the public good of security in terms of inclusion or exclusion.

Following this criteria, we can distinguish between two different approaches. On the one hand, security can be conceived as a universal public good, poorly selective on a territorial basis, being available for every individual-at least potentially-whether or not it is delivered by an authority of a political nature. On the other hand, security can be conceived as a territorially selective public good. The access to this good would be inextricably linked to a specific feature of the political authority (namely the monopoly of legitimate violence), within specific territorial contexts.

The first approach to security (intended as a universal and not-selective public good) includes those studies that broaden the concept of security, aside from the political sphere, to many other spheres of individual and collective action (economic, social, environmental etc.). Under this approach we can include the so-called "critical security studies" (Booth 1991, 2005; Wæver 1995; Buzan et al. 1998; Jones 1999; Williams 2003) and the studies on "human security" (King and Murray 2001; Burgess and Owen 2004; Owen 2004; Newman 2010).

The second approach to security (intended as a territorially selective public good) includes those researches that narrow the concept of security only to the political sphere, limiting the concept extension to the nation State sovereignty and its territorial branches. Fall into this approach the studies on "national security" (Wolfers 1952; Donnelly 2000; Kolodziej 2005), and studies that analyse the regional and urban dimensions of security (Lagrange and Zauberman 1991; Hebberecht and Sack 1997; Edwards et al. 2017).

\section{Democracy and democratic quality}

To define democracy is a particularly sensitive exercise, over which the greatest scholars of politics have struggled, with answers that have not always converged. One of the definitions on which there is, however, agreement in the literature is the so-called "minimal definition" of democracy, which lists the fundamental factors empirically verifiable and measurable that need to be present, all and simultaneously, to call a political regime as democratic (Dahl 1971; Linz 1978; Sartori 1987; Schmitter and Karl 1993; Morlino 2003). This definition envisages that all regimes are democratic which present at least the four following requisites: (a) universal suffrage, male and female; (b) free, competitive, recurrent and correct elections, on the outcome of which the election of representatives and governmental roles depend; (c) more than one party with guarantees of competition, and opposition; (d) different and alternative sources of information. These few requisites of a procedural nature must not deceive us, for, to be fully satisfied, they require powers, institutions, and articulate, consolidated processes, which show that democracy is a complex political regime. It presents three complementary facets, though analytically separate, and its concrete functioning depends on their combination. The first configures the structure and processes of political representation and government functions: in a word, the characteristics of democratic politics. The 
second identifies structures and processes of public decisions, namely the ways in which democratic policies are formulated and implemented. Both interact with a third dimension, that of polity, inherent in the spheres of territorial autonomy and sovereignty both of the central government and of the peripheral institutions.

The three facets of democracy contribute to determining what Morlino defines as "quality democracy", namely "that stable institutional order which through correctly functioning institutions and mechanisms creates freedom and equality of citizens" (Morlino 2003: 228). Conceived in this way, the quality of democracies may be empirically analyzed in eight analytical dimensions. Five are procedural dimensions, since they prevalently concern the rules and only indirectly the contents: rule of law, participation, competition, vertical accountability (which binds the electors to the elected) and horizontal accountability (which links, in a game of reciprocal checks and balances, the constitutional organs). To these are added two substantive dimensions, since they specifically concern the content of democratic government action: enjoyment of fundamental freedom rights (civil, political and socio-economic) and conditions of equality, on both the political plane and the socio-economic one. The last dimension is defined as an "outcome dimension", as it concerns the political system's capacity to respond (responsiveness) to citizens' questions (Morlino 2011).

As is clear from the comparative analyses conducted up to now (see, in particular, Diamond and Morlino 2005), the data available enable the phenomenon to be framed and interpreted both in terms of lesson drawing (hence generation of hypotheses) and as a research field fit for validating past hypotheses (Tebaldi and Calaresu 2009, 2015b). As for the empirical size of each dimension and the relations running between them, what emerges may be summarised in the following points: (a) the centrality of competition and participation, which always tend to co-vary, as key-factors to supply the development of the other dimensions, especially responsiveness, to the point of being acknowledged as authentic "engines" of democratic quality (Diamond and Morlino 2005: xi); (b) the close ties between rule of law, accountability (horizontal and vertical) and freedom, so that with an increase in one, an increase usually occurs in the others; (c) low performance, compared with the other dimensions, of the levels of equality, except, and in relative terms, in the economically richer and socially more advanced democracies.

\section{City and local governance}

Following a rediscovery of the "local" in the Seventies, it was from the subsequent decade that the urban dimension acquired centrality in political science research programmes and the city appeared as a unit of analysis and an economically and politically important actor (Saunders 1981; Page and Goldsmith 1987; Sharpe 1988) in the study of western democracies. Only since the Nineties, however, thanks to the enormous development of studies on local and urban governance, can it be stated that the city has become a privileged subject of study to understand on what conditions and through which interactions a democratic government may be guaranteed to be effective and efficient at a peripheral level, in local contexts that are increasingly complex economically, institutionally and socially (Batley and Stoker 1991; Le Galès 1995; Lefèvre 1998; Bogason 2000). This research trend, developed above all in the European sphere, fits into a period in which the urban-based political actors are increasing their visibility and capacity for negotiating with the actors on a central and regional scale (Le Galès 2002), also appealing to the legitimisation and financial resources granted them by supranational institutions, in particular the European Union.

To define in terms that can be operationalised what is meant by the term city and how this unit of analysis can be used for empirical analysis, we adopt Pichierri's (2002: 48-49) methodological proposal and assume that the minimal requisites of the definition of city are as follows:

1. The existence of a territorial area that presents socioeconomically homogeneous features and a local intensification of the relations enabling a boundary to be established between "inside" and "outside";

2. The existence of a collective actor (or coalition of actors), whose action is the result of collective, legitimised decision-making mechanisms.

To identify the area, the administrative boundaries are only a departure point and a reference point. Similarly, the collective actor that interests us does not necessarily, less still entirely, correspond to the local government. Local government, understood as a set of public institutions with the task of governing in the local sphere, is one of the components of a complex mechanism of regulation composed on many local actors (institutions and others) interrelated with each other, for which the notion of governance is used nowadays with increasing frequency. With the term governance, applied to the local democratic context, here is meant "a process of coordination of actors, social groups and [local] institutions, for achieving objectives discussed and defined collectively in fragmented, uncertain environments" (Le Galès 1998: 77).

\section{Do politics determine security policy?} The problem of the rule of law

Security in a democracy, as for the other political regimes, is one of the essential conditions; we might say a 
prerequisite, for the application of all the others. For it is on collective security and civil order that the ideal social contract is founded, which binds members of a community to each other, around a form of governing power able to guarantee peaceful coexistence. So democracies, too, like any other regime, need rules and structures set up to guarantee the protection of a social good of such political and civil worth. The security phenomenon, at whatever territorial level it is analysed, calls without exception for the discouragement and repression of crime to be among the essential functions of those holding legal power, which in democracy is exercised within a rule of law framework.

On this matter, according to the most accredited literature, it may be stated that the rule of law in quality democracies envisages security as one of its most valued political products. It is a product, however, that takes on qualitative value in democracies when it is accompanied by certain elements pertaining mainly to both the correlation between action to prevent/repress crime and efficacy of the structures and sanctions in place against illegality, and to other conditions that may be clearly identified in the definition of rule of law proposed by Morlino (2003: 232-233). He specifies that the concept of rule of law may not be limited to the "operativeness of any legal system". In effect, very few doubt that "the principle of superiority of the law [...], a certain, albeit limited, ability to have the laws respected by the authorities in charge of this, the characteristics of non-retroactivity, generality, stability and clarity are minimal elements for the existence of any civil order".

According to the definition he formulates, to speak of security in an efficient and effective rule of law situation, a generic reference to an acceptable degree of crime is not enough, as this result needs to be combined with the organisations and processes by which it is obtained, namely the concomitant action of police forces and judicial and prison apparatuses that are efficient and respect civil guarantees. All these aspects constitute the set of institutionalised rules, procedures and organisations around which the penal system of national governments takes shape. Thanks to the penal system, the democratic rule of law presides, at the level of national politics, over the fundamental tasks of discouragement and repression of crime. Seen from this angle, the literature going back to Weber's theory of the state indicates civil order and the correlated security policies as a fundamental objective of modern state organisations, meant in their top-down, centralised configuration. As it is an objective derived from the centralisation of political power, the conservation of civil order tends to concern, also in democratic regimes, the institutionalised interaction between central governments, bureaucratic agencies, judicial and police organs and representative assemblies.
It cannot be ignored, moreover, that in recent decades the West European democracies have shown, as much for decisions on security, as for the management of security, a clear tendency towards redefining models of territorial governance, the common denominator of which consists of delegating important functions of crime prevention and control to local powers. On this subject, a decisive issue is the generalizability and applicability of decisionmaking and management instruments with a decentred nature for improving security (and therefore democratic quality) in the different territorial contexts in which individuals operate and relate with each other, with particular regard to the urban dimension of social action (Calaresu 2013; Calaresu and Tebaldi 2015).

\section{The problem of consensus}

In order to discourage and prevent crime, however, referencing solely to the rule of law penal system does not fully describe the field of action of democratic institutions. At least three sectors of public intervention should also be mentioned, each distinguished by specific public policies, actors and decision-making procedures: the early prevention sector, aiming at intervening in the agencies of socialisation most influential in youth, such as the family and school; the sphere of social prevention, aimed at controlling those environmental factors (quality of social life, urban decay, poverty, social atomisation) capable of favouring crime; the field of situational prevention, aimed at limiting the threats to individual security via dissuasive forms and instruments (formal and informal surveillance, alarm and control systems) able to increase the difficulties and risks of criminal practices, as well as diminish its returns (Barbagli and Gatti 2005).

To say, therefore, that security pertains to the degree of effectiveness of the rule of law means to observe only one of the vehicles by which it is pursued. Usually, in fact, a considerable number of security policies fall not so much within the procedural, organisational and regulatory measures aimed at suppressing crime, as within the finetuning of public instruments and strategies targeting its prevention.

This complex set of problems and decisions constitutes the field of analysis of security policies and inevitably intertwines with the factors of democratic politics characterising it on the input side: in the course of the processes of formation of consensus and competition for the people's vote. Seen from this side, security may be classified as one of the fundamental issues around which, particularly from the Nineties onwards, both the electoral programmes of political parties and their competitive strategies revolved. In that same period the salience of the security issue grew exponentially, as much in society (in the somewhat simple terms of "perceived 
security") as on the political agenda of national and local decision-makers.

As is well known, in contemporary times democracy has taken on a prevalently representative nature. In this sense, it has become configured as the regime of responsibility due to its capacity to respond to social problems. The main liberal democracy theories founded the proper functioning of the representative mechanism precisely on the bonds between accountability and responsiveness.

Democracy, in a procedural sense, is a method of making decisions on collective problems. It is, however, a method that, in order to operate with full effect, has to submit to precise normative and functional requisites: the rules that make the delegation of power from many to few tolerable and socially acceptable, based on a formal representative mandate. Representatives wishing to define themselves as such and to be able to exercise the respective decision-making powers, have to have succeeded in an institutionalised competition that selects the competitors, translating the vote of those represented into parliamentary seats and/or government roles.

The concept of accountability is the authentic "transmission belt" between the will of the people expressed by the democratic competition and the level of responsiveness of the government decisions. The winners of the democratic contest cannot exercise their governing power without taking care of the promises made to obtain those votes and the expectations of those who expressed them in seeing the promises materialise in government policies. Not so much as a contingent fact-the vote to be won here and now-as an expectation regarding the future: the legitimate expectation, namely, of the representative elected to see his election confirmed in subsequent rounds of elections, each time the mandate expires. As Sartori correctly pointed out (1987), the competitive theory of democracy becomes a powerful instrument of "payment" between electors and elected, when the latter, the incumbents, are conceived in their role of candidates for a new election; namely, when responsibility to the elector is enmeshed in the rules observed by the competitors, based on the "rule of anticipated reactions". The challengers, in turn, will be influenced by this way of understanding the relationship with the electors, for in order to be credible winners in future competitions they will necessarily have to promise policies that are not just pleasing for the majority, but able to be tangibly realised and effectively assessed.

It is not surprising, therefore, that in the relationship between the parties (office seekers) and the electors (policy seekers) a fundamental component consists of the continuous search for attractive issues, in terms of both political supply and demand. Recent decades have shown how important the theme of security has become in the dynamics of consensus, so much so as to rise, at certain times in the political life of contemporary democracies, to being a leading theme in the public debate, ahead even of electoral campaigns, at all levels of government and above all at a local level. In western democracies, in particular, ambitious objectives like the struggle against organised crime and the guarantee of greater security of citizens have become welded to issues of a social nature linked especially with the pressure and widespread fears of migratory phenomena, making up a "programmatic medley" upon which the promises, remedies and challenges of the political parties have concentrated.

On this subject, some authors maintain that the preferences and capacities of the dominant actors mould the interpretative frames of the social problems, which, in turn, determine the perceptions of security and insecurity of the dominated actors. It is through this process of manipulation that the threats to security can be amplified, with a contagious effect, to reach the threshold of social alarm; and it is through this mechanism that the need for security can be turned into a strategy of securitisation (Wæver 1996).

Following this perspective, any problem may consequently become a security issue on the grounds of an evaluation and choice carried out by a "judging subject" (a governor, state actor, the heads of an administrative agency or military body, a political party élite, the leaders of an opposition movement, etc.) capable of raising it to the rank of "existential threat" for a specific "referent object" (the community or a part of it, the regime, organs of state, production facilities or processes, social groups, etc.), to fuel a socially widespread perception of it and thus determine its "securitisation". Once an issue is "securitised" it obtains, due to its gravity and urgency, a higher status compared with ordinary issues. This enables, in turn, superordinate placing on the political agenda of those governing and immediate entry among the extremely urgent policy problems; this leads to the possibility granted to decision makers to use emergency procedures able to surpass the normal procedural, administrative and legislative ties.

\section{The problem of participation}

Observing the practicality of the representative circuit, few people have doubts on the necessary presence of a certain degree of participation, if and when citizens have the chance, for good democratic functioning, namely to express disagreement or consensus on the decision-makers and decisions concerned. This statement, apparently taken for granted, nevertheless nurtures some dilemmas of a theoretical and methodological nature. For if it is assumed that modern democracies have an eminently representative character, where an important part of 
public decisions are made by agents elected by the people and delegated by them to govern, it is however just as true that the different empirical theories of democracy cannot ignore the existence of a certain degree of tension between the concept of representation and that of participation. Those who emphasise the clear prevalence of the former in the concrete evolution of current democratic regimes are countered by those who, though not ignoring the crucial role of the representative phenomenon, underline the need to improve the functioning of democracies, increasing the opportunities for institutionalised political participation beyond the classic channels of representation: both to grant greater legitimacy to the representatives, and to sustain them in their decision-making function, and again, to involve the decision-takers in the phases of drawing-up the political agenda and implementing the public decisions. This appears particularly important when attention is paid to complex, controversial decisions like those involved in security and public order, the results of which are felt in an extremely urgent (and often distorted) way by public opinion and organised citizenship, to the extent that applications are sometimes made for self-protection for security at a territorial level.

For this reason, those engaged in politics today, be it at a professional-administrative level or from a scientificexplanatory point of view, have become increasingly interested in understanding how, why and to what extent the coupling of new participatory instruments with the principle of delegation and representation can improve the quality of democracy as regards the production of efficient, fair policies. In particular, the interdisciplinary debate has led to three alternative forms of participation, potentially capable of subtracting the democratic political process from the negative effects produced both by generalised apathy and by the progressive success of the NIMBY syndrome. We are referring to direct participation within the sphere of deliberative democracy mechanisms; to mediated participation by groups in the processes of contractual democracy; to the selective participation of groups and institutions at decision-making tables regulated by pactional and contractual instruments (Calaresu 2012, 2016).

When referred to the theme of security, the latter remarks take on particular importance, above all when they appear to be nurturing a serious challenge to that consolidated tradition of thought going back to Weber's theory of the state, already mentioned earlier. Although this theory indicates civil order as a fundamental objective of modern state organisations, understood in their top-down, centralised configuration, it is a model that seems nowadays to lose an explanatory capacity, where new participatory forms of a pactional and contractual type are observed that delegate important crime prevention and control functions to local powers.

It is clearly a case of issues that correlate a large number of variables between them, the resolution of which cannot, however, disregard an adequate configuration of the territorial coordinates that regulate the participatory behaviours of local subjects and institutions, delimiting what we might define, due to its polyedricity and the composite spectrum of its empirically observable elements, the "spatial prism" of security policies.

On the theoretical plane this connection provides some research questions that we can summarise as follows: how and how much does the territorial variable concur in sketching out the salient aspects of the institutionalised participation of groups and local authorities in security policies? How much do the ties and opportunities linked with the city territory count in sanctioning, legitimising and strengthening these participatory spaces? What relation is there, finally, between centre-periphery logics and the quality of the decisions made when a public good is at stake that particularly characterises the interaction between individual and territory, i.e. the security of the physical space in which we live?

\section{Does polity determine security policy? The problem of citizenship}

Before going ahead, it is worth focusing on some theoretical and conceptual cornerstones usually used to explain the degree of interaction and reciprocal influence between the dimension of physical space (what we have previously called the polity dimension) and the participatory dimension of the democratic political processes that lead to binding decisions on individual and collective security.

The intertwining of these factors belongs to a complex problem that since classical times has attracted the main authors on political thought, and continues today to involve-opening up many areas of interaction and contamination-just as much the social sciences as the territorial sciences.

Whether it is described as government by the people or read in terms of government for the people, the concept of representative democracy, conceived in the classical liberal-electoral sense, seems to justify individual political participation based on clear territorial delimitation. The concept of citizenship cannot, in effect, be expressed without reference to a territory of belonging, a specific democratic polity, to a physical space, as well as political, that delimits the exercise of the rights of participation. For Aristotle this space is the polis, the city, from which comes the concept itself of citizenship; in modern times, democratic polity has corresponded to the national state and its internal territorial divisions, though new forms of 
citizenship are developing that belong to territorial characters of a supranational nature (above all, the European Union).

It is true, nevertheless, that the simple juxtaposition of political rights and citizenship does not satisfactorily reveal the complexity of democratic action; above all, it does not manage to throw full light on the spatial prism of democracy, where, in particular, participative behaviours from the bottom can be observed of individuals operating within specific territorial areas (especially within the urban dimension), even if they do not organically and legally possess the status of citizens of that specific territory. Indeed, if we begin with this remark, the participatory forms with the highest rate of inclusiveness, abandoning the term citizen in favour of that of stakeholder, manage to embrace anyone who has an interest at stake, i.e. all those who depend on the policies in place on a territory, though they are not citizens of it. Observed from this bottom-up perspective, those individuals that live on the territory without being residents or having legal citizenship also produce participative potential. Commuters, who work in the city though they do not live there, city users, who neither work nor reside within urban boundaries but use the city for cultural, economic and social consumerism and, finally, migrants, all come under the first type. All these categories are highly influenced by the choices made at a local level for a variety of public policies, of which policies for security and public order are one of the cornerstones. In brief, they are stakeholders who, through participative forms able to include their voice, aim at re-equilibrating their position compared with the privileged categories of the third generation metropolises: the citizen-inhabitants, who have access as such to the multiple electoral circuits of different territorial levels, and the metropolitan businessmen, who thanks to their own resources can affect urban policies by lobbying or by their involvement in the local consultation arenas.

If the institutionalised interaction between central and peripheral actors in security pacts may be considered a "participative antidote" to the widespread malaise afflicting a large number of the mature polyarchies, what are the bonds existing between the territorial structure of democratic regimes, the new problems of metropolitan political participation and the improvement in the democratic governance of cities security brought by the new instruments of consultation? Assuming that a quality democracy cannot avoid assuring that all associates are in practice put in a position to use the rights of participation and contestation with the same possibility of influencing public decisions, is it true that the new participatory forms, precisely because they tend to "release" participation from the citizens, to connect it to other aspects of territoriality, constitute an actual opportunity of equality on important decisions like those on security and public order? And how much can they condition the levels of affection, loyalty and trust interiorised by citizens with respect to the democratic institutions? Do they not risk reproducing, in fact increasing, social differences, thus negatively affecting the levels of trust in democracy?

Furthermore, what influence can pactional instruments have in improving the condition of security perceived by citizens, without at the same time weakening the actual decision-making capacities to prevent crime? When we speak of security policies, are we moving then towards a huge qualitative change in terms of greater democratic efficiency and equity, or are we embarking, on the other hand, on an uncertain path, with the progressive weakening of central government institutions, the arrival of new forms of centre-periphery conflicts, and the rise of institutionalised mechanisms that, under false pretences, make social control pervasive, evil and intolerable?

\section{Conclusions: Does security policy determine politics and polity?}

Assuming that the relation between individual, democracy, participation and territory tends to become clear, at least on a theoretical scale, at the different problematic levels of which we have just defined the salient aspects, a decisive question concerns the generalisability and applicability of decision-making instruments of a pactional type with a decentred nature to improve security (and therefore democratic quality) in the different territorial contexts in which individuals operate and relate with each other, with particular respect for the urban dimension of social action.

A crucial testing ground to understand if, and up to what point, the pactional instrument is a decisive element for defining city democracies (Tebaldi and Calaresu 2015a) is therefore the development of security policies in a new polity dimension that sees local power in the front line (institutions and groups), apparently accompanying the-and in many people's expectations freed by the-traditional central powers of the state.

In the inter-state context, security (let us speak then of "internal security") means, first of all, acting sine cura; namely, conducting one's existence without worrying about who might endanger or upset the monopoly of legitimate violence of the state through the use of more or less unforeseeable, frequent and intense illegitimate violence, more or less organised and spread through all the instruments usable for the occasion.

If illegitimate violence is effective and not efficiently sanctioned, it endangers the territorial, organisational and political control of any polity, and tends to threaten its values that are considered fundamental (core values). 
To act in security, therefore, does not just mean to take shelter from illegitimate offensive actions, but also to eliminate or diminish the risk or threat factors of the values mentioned above. As we have already observed, the public debate on security has spread over the last decades at two levels concerning both the practical plane of policies pursued and the theoretical one of analytical and explanatory instruments aimed at justifying these policies in democratically acceptable terms.

From this point of view, some recent contributions appear to have disclosed some aspects of the recent pactional experiments with urban security that seem to fuel more than a few doubts about their innovative capacity. Security pacts, far from redefining the governance of urban security in a substantial sense, basically propose again, with new inter-organisational procedures, the traditional situation and logics, founded on the dependence of peripheral powers on central government bodies. With all the consequences concerning the possibility of introducing new governance instruments, more sensitive to urban transformation and to the needs of security that this transformation introduces into the public debate and public agenda. Without, however, penalising the applications for participative equality that the disadvantaged sectors of the urban community insistently claim.

What we have analysed up to now leads us nevertheless to formulate new questions and new interpretative hypotheses inherent in the development of public security policies.

Consistent with what Lowi states (1964) on the activation of specific arenas of power and public decisionmaking, it is fair to conjecture that certain types of policies-including primarily security, a crucial element in peaceful, organised co-existence, especially in the urban environment-could determine the features of politics and the actual structure of democratic quality.

Up to what point, then, can democracies, at any level of territorial sub-division, accept the temporary or lasting suppression of some kinds of freedom, just to raise their level of internal security in metropolitan governance? Can it be said that the security policy tends to determine both the politics of democratic quality and its polity, namely the territorial criteria that legitimise participation? Can we conjecture that the need for responsiveness and accountability, when there is a primary necessity like security at stake, tends to relegate other dimensions of democratic quality, such as the freedom and equality of popular participation, to second place and thus to redefine the ties between democracy, participation and territory? Looking at it through the lens of urban security policies, it does not seem risky to state that the spatial prism of democracy, first evoked due to the multiple facets into which it manages to break down the concept of participation, tends on the other hand to drastically reduce, thus understood, its refractive capacity.

Metaphors aside, what seems to emerge from our reflection is the fact that participative freedom and equality, when the primary good of security is endangered, may be taken back to obviously more narrow-minded territorial principles of the concept of state citizen (the metropolitan area or the city rather than the district or single street of residence), without, on the other hand, managing to give voice to the interests of those excluded: who, if anything, may be excessively penalised precisely by the participation of the few who have new participatory channels available.

To speak of decentralisation, in this sense, is not misleading. Territorial belonging, once more and even if remodelled from the bottom, may hinder participation making it unequal; this tends to be aggravated when the criterion of territorial belonging merges with other attributable characters of a cultural type (ethnic, religious, linguistic, etc.) raising reasonable doubts about the democratic quality of those collectivises that, feeling their security at danger, do not hesitate to belittle and delegitimise the participation of minority groups considered antagonistic.

\section{Authors' information}

Mauro Tebaldi is an associate professor of Political Science at University of Sassari, Department of Political Sciences, Communication Sciences and Information Engineering. His research interests and publications are in the areas of public policy analysis and the quality of democracies. He has written widely on academic journals including Rivista Italiana di Scienza Politica, South European Society \& Politics, Quaderni di Scienza Politica, Comunicazione Politica and other leading scholarly journals. Among his recent books, he edited Sicurezza, libertà, democrazia (II Mulino, forthcoming).

\section{Acknowledgements}

The authors wish to thank the contribution of Giovanni Maciocco at University of Sassari for discussing and debating ideas, concepts and methods related to this work from a wider disciplinary perspective. A special thanks to Christine Tilly, and Marco Calaresu for their continued support in proofreading and editing this work.

\section{Competing interests}

The author declares that he has no competing interests.

\section{Funding}

The research has been partially funded by a PRIN National Grant 2010-2011 (Ministry of Education, University and Research) entitled "Crisi economiche e qualità delle democrazie in Europa-Economic crisis and the quality of democracies in Europe". Scientific National Coordinator: Leonardo Morlino. Leading Institution: Libera Università Internazionale degli Studi Sociali Guido Carli (LUISS), Rome, Italy. Scientific Local Coordinator: Mauro Tebaldi. Local Institution: University of Sassari, Department of Political Sciences, Communication Sciences and Information Engineering, Sassari, Italy. Duration: 36 months. Protocol number: 2010WKTTJP_007. Area: 14

Received: 9 September 2016 Accepted: 14 October 2016

Published online: 21 October 2016 


\section{References}

Barbagli M, Gatti U (2005) Prevenire la criminalità. II Mulino, Bologna

Batley R, Stoker G (eds) (1991) Local government in Europe: trends and development. Macmillan, London

Bogason P (2000) Public policy and local governance: institutions in postmodern society. Edward Elgar, Cheltenam

Booth K (1991) Security and emancipation. Rev Int Stud 17(4):313-326

Booth K (2005) Critical security studies and world politics. Lynne Rienner, Boulder

Burgess J, Owen T (2004) Special section: what is "human security"? Secur Dialogue 35(3):345-387

Buzan B, Wæver O, de Wilde J (1998) Security: a new framework for analysis. Lynne Rienner, Boulder

Calaresu M (2012) La politica di sicurezza urbana in Italia. L'esperienza dei "patti per la sicurezza" nel triennio 2007 2009. Rivista Italiana di Politiche Pubbliche 3(7):387-418

Calaresu M (2013) La politica di sicurezza urbana. II caso italiano (1994-2009). Franco Angeli, Milano

Calaresu M (2016) The top-down instruments for governing crime and disorder: what lessons can be drawn from the Italian experience (2007-2011)? In: Peršak N (ed) Regulation and social control of incivilities. Routledge, New York

Calaresu M, Tebaldi M (2015) Local security policy and the protection of territory: an analysis of the Italian experience (2007-2009). City Territ Archit 2(1):1-18

Dahl RA (1971) Poliarchy. Yale University Press, New Haven

Diamond LJ, Morlino L (eds) (2005) Assessing the quality of democracy. Johns Hopkins University Press, Baltimore

Donnelly J (2000) Realism and international relations. Cambridge University Press, Cambridge

Edwards A, Devroe E, Ponsaers P (eds) (2017) Policing European metropolises. The politics of security in city-regions. Routledge, New York

Hebberecht P, Sack F (eds) (1997) La Prévention de la Délinquance en Europe. Nouvelles Stratégies. L'Harmattan, Paris

Jones RW (1999) Security, strategy and critical theory. Lynne Rienner, Boulder

King G, Murray CJL (2001) Rethinking human security. Political Sci Q 116(4):585-610

Kolodziej EA (2005) Security and international relations. Cambridge University Press, Cambridge

Lagrange H, Zauberman R (1991) Introduction: du Débat sur le Crime et I'Insécurité aux Politiques Locales. Déviance et Société 15(3):233-255

Le Galès P (1995) Du gouvernement urbain à la gouvernance urbaine. Revue Française de Science Politique 45(1):57-95

Le Galès P (1998) La nuova "political economy" di città e regioni. Stato e Mercato 52:53-91

Le Galès P (2002) European cities, social conflicts and governance. Oxford University Press, Oxford
Lefèvre C (1998) Gouvernements métropolitains et gouvernance dans les pays occidentaux. Politique Manag Public 16(1):35-59

Linz JJ (1978) The breakdown of democratic regimes: crisis, breakdown and reequilibration. Johns Hopkins University Press, Baltimore

Lowi TJ (1964) American business, public policy, case-studies and political theory. World Politics 16(4):677-715

Morlino L (2003) Democrazie e democratizzazioni. II Mulino, Bologna

Morlino L (2011) Changes for democracy: actors, structures, processes. Oxford University Press, Oxford

Newman E (2010) Critical human security studies. Rev Int Stud 36(1):77-94

Owen T (2004) Human security. Conflict, critique and consensus: colloquium remarks and a proposal for a threshold-based definition. Secur Dialogue 35(3):373-387

Page EC, Goldsmith MJ (eds) (1987) Central and local government relations: a comparative analysis of west European unitary states. Sage, London

Pichierri A (2002) La regolazione dei sistemi locali. Attori, strategie, strutture. II Mulino, Bologna

Sartori G (1980) La politica. Logica e metodo in scienze sociali. II Mulino, Bologna

Sartori G (1987) The theory of democracy revisited. Chatham House, Chatham

Saunders P (1981) Social theory and the urban question. Hutchinson, London

Schmitter PC, Karl TL (1993) What democracy is... and is not. J Democr 2(3):75-88

Sharpe $\amalg$ (1988) Local government reorganization: general theory and UK practice. In: Dente B, Kjellberg F (eds) The dynamics of institutional change. Local government reorganization in western democracies. Sage, London

Tebaldi M, Calaresu M (2009) Valutare la democrazia. Introduzione all'analisi della qualità democratica. Aracne, Roma

Tebaldi M, Calaresu M (2015a) "Democra-city": bringing the city back into democratic theory for the 21st century? City Territ Archit 2(13):1-15

Tebaldi M, Calaresu M (2015b) The pursuit of quality: assessing democracies... to save democracy? Open J Political Sci 6(1):1. doi:10.4236/ o.jps.2015.61001

Wæver O (1995) Securitization and desecuritization. In: Lipschutz RD (ed) On security. Columbia University Press, New York

Wæver O (1996) European security identities. J Common Mark Stud 34(1):103-132

Williams MC (2003) Words, images, enemies: securitization and international politics. Int Stud Q 47(4):511-531

Wolfers A (1952) National security as an ambiguous symbol. Political Sci Q 67(4):481-502

\section{Submit your manuscript to a SpringerOpen ${ }^{\circ}$ journal and benefit from:}

- Convenient online submission

- Rigorous peer review

- Immediate publication on acceptance

- Open access: articles freely available online

- High visibility within the field

- Retaining the copyright to your article

Submit your next manuscript at $\boldsymbol{\nabla}$ springeropen.com 